\title{
HUMAN FOIBLES AND PSYCHOANALYTIC TECHNIQUE: FREUD, FERENCZI, AND GIZELLA PALOS
}

\author{
Benjamin Kilborne
}

This paper explores relations between human conundrums and psychoanalytic technique and theory through the relationship between Freud and Ferenczi. Rather than vilify (or lionize) either figure, the paper seeks to see into their struggles and conflicts, and to draw from correspondence and writings a portrait of a relationship. The paper describes not two dusty figures drawn from the closet of history but rather two live, flawed, and struggling human beings whose rational ideas about what they were doing could never keep step with their emotions. There is therefore much to be learned from their relationship: about transference and countertransference, about boundaries and friendship, about rivalry and despair, and about shame.

KEY WORDS: psychoanalytic technique; human foibles; psychoanalytic history; shame; idealization; trauma; Freud-Ferenczi relationship.

DOI:10.1057/palgrave.ajp.3350045

All history is the interpretation of the present

Benedetto Croce

\section{FEELING THE PULSE OF PSYCHOANALYTIC HISTORY}

In this paper I will explore the Freud-Ferenczi relationship with an eye towards elucidating shame dynamics and their pertinence in the generation of theory. It is often thought that psychoanalytic theory represents progress, and that advances are advances because they are more contemporary or more modern. Therefore, an account of the messy and often confused and confusing relationships between theoreticians a century ago may provide a reminder that theoretical progress is of little use if it does not allow us to be at once more respectful and more effective in treating patients.

Furthermore, difficulties in all human relationships cannot but find their ways into psychoanalytic work. The history of the social sciences is curiously full of ahistorical and positivistic assumptions ${ }^{1}$ to which the

Benjamin Kilborne, Ph.D., Member, American Psychoanalytic Association, International Psychoanalytic Association. In private practice in West Stockbridge, MA.

Address correspondence to Benjamin Kilborne, Ph.D., 5 Lenox Road, West Stockbridge, MA 01266; e-mail: bkilborne@aol.com 
history of psychoanalysis has sometimes fallen prey. Using history to reassure ourselves that such messes happened only in the past and that we are now beyond them runs the danger of presentism, and places the conundrums and personal conflicts of our forebears beyond our reach. Since it is in the nature of our work to involve two warm-blooded and necessarily flawed human beings, a recognition today of how valiantly both Freud and Ferenczi struggled with their professional responsibilities, their friendships, their loyalties, their ambitions, and their anxieties can serve as useful reminders that no theory, no matter how contemporary, can save us from struggles of a similar kind. All we can do is to marshal our psychoanalytic resources, our understanding of theory and technique, our clinical experience, our personal grasp of our own feelings and ideas about what we are doing, and our respect for human suffering in the hope that these will be sufficient. Often, as in the case of Freud and Ferenczi, they are not.

There is a second reason to re-examine the Freud-Ferenczi relationship with an eye towards inquiring into its meaning for us today. That has to do with our approach to the history of psychoanalysis. It is a truism that we need to learn from our mistakes. This also applies to learning from the mistakes of our predecessors. If we cannot learn from their mistakes, we are unlikely to learn from our own. Particularly in a political climate in which smugness reigns, and mistakes are often recognized only in one's political opponents and never in oneself, the Freud-Ferenczi relationship can serve today as a resource: to raise important questions, to suggest ways in which our psychoanalytic ideas and techniques can be used in exploratory fashion on persons who are not on our couch, and to provide inspiration for our work under particularly difficult circumstances and in difficult times. Thus, the history of psychoanalysis is not an empty exercise in applied psychoanalysis, using the personal biographical data that correspondence, papers, and publications can provide; it is a living thing of which we are ourselves a part. There are therefore ways of using analytic inquiry into our own preoccupations, wishes, fears, perceptions, and distortions that are directly applicable to our understanding of the past. The purpose of this paper is not to flaunt the mistakes of either Freud or Ferenczi; rather, it is to better understand what we can learn today from the mistakes-and brilliance-of both.

It is worth noting at the outset that Freud's self-analysis spared him the shame of having to reveal himself to another person. In other words, Freud's experience of analysis bypassed an analysis of shame because there was no other person before whom he felt ashamed. In this the experience of Freud and Ferenczi differed fundamentally. For Ferenczi, revealing his faults and shortcomings occupied an important place in his relationship with Freud, and was all the more confusing to him because of his struggles with 
idealization; Ferenczi's need to idealize Freud served many functions, one being a defense against his own shame. It is perhaps useful to underscore how idealization and shame can play off of each other in relationships, each intensifying the other and leading sometimes to an inner experience of basic conflict, splitting, and insubstantiality. Ferenczi's need to be shamed and Freud's need to be idealized, Ferenczi's need to idealize Freud and Freud's to shame Ferenczi-all play a part in their relationship, together with the ways in which both men deal with (and fail to deal with) their shame.

\section{BACKGROUND AND CHRONOLOGY}

In the context, then, of the Freud-Ferenczi relationship, it can be useful to consider side by side Ferenczi's theories of trauma and Freud's seduction hypothesis and his theories of childhood sexuality. But first let me provide a context for the Freud-Ferenczi relationship and a chronicle of Ferenczi's relationship with Gizella Palos, the woman who he had in analysis and who, at Freud's insistence, he eventually married.

Sandor Ferenczi was born in 1873, the eighth of 12 children. Ferenczi's father, whose favorite Ferenczi was, died when Ferenczi was 15. Consequently, Ferenczi did not have a father who might have seen him through the storms and sexual conflicts and rivalries of adolescence, an absence that made Freud all the more central to Ferenczi's life. In what I have read, Ferenczi's mother is a shadowy figure. Ferenczi earned his medical degree at the University of Vienna, and then returned to Budapest in 1897, working in community hospitals and opening his private practice (which included work with the courts) several years later.

The woman Ferenczi was to marry at Freud's insistence, Gizella Palos (born Altschul), was a member of a family known to Ferenczi from childhood in the town of his birthplace (Mistole, Hungary). Ferenczi's younger brother Lajos married Gizella's daughter Magda, sister of Elma. Furthermore, both Magda and Gizella's first husband, Geza Palos, were strongly opposed to any union between Ferenczi and Gizella. Palos was older than Gizella, who was older than Ferenczi, and constituted a forbidding father figure.

Ferenczi first has an affair with Gizella in 1900, after which their relationship continues despite Gizella's marriage to Geza Palos. Somewhere around 1910, Ferenczi takes Gizella into analysis. Some months thereafter, Gizella's short analysis being terminated, she asks Ferenczi to take her daughter Elma (Ferenczi's brother Lajos' sister-in-law) into analysis. Ferenczi agrees (July 14, 1911). Waters become murky when Elma's lover shoots himself and Elma sinks into a deep depression. In response to Elma's anguish, and feeling himself to be the object of strong desires, Ferenczi 
struggles with his own feelings of affection for Elma. Ferenczi confides to Freud (December 1911) "Elma became especially dangerous to me at the moment when - after that young man's suicide—she badly needed someone to support her and to help her in her need. I did that only too well, even though I held my tenderness in check with difficulty for the moment. But the path was cleared and ...she has won my heart."

Ferenczi sends Elma to Freud to finish the analysis. Ambivalence plays its part here as in Ferenczi's relationship with Gizella. Ferenczi both hopes that Elma will work through fantasies of marrying him and thus be able to reassure him that she has chosen him freely (something he has difficulty doing himself), and that the analysis will not work, and Elma will prove herself unworthy. Ferenczi appears to be relying on Freud to relieve him of his ambivalence without his having to take a stand, a reliance clearly difficult for Freud to handle. It is even possible that the very sexual nature of Ferenczi's desire for Elma (with its potential for children) frightened Freud and made Freud fearful that he would lose the intensity of Ferenczi's admiration and love.

In the end, Freud sends Elma back to Ferenczi for a final bit of analysis. Ferenczi writes to Freud (April 25, 1912) that if Elma does not "admit her resistances...then I am firmly resolved to give her up," a remark that would seem to pick up on dynamics in the analysis of Ferenczi by Freud. Freud persistently refers both explicitly and implicitly to Ferenczi's resistance, and these dynamics infiltrate accounts of Ferenczi's struggles over marrying Gizella. Freud writes to Ferenczi (March 12, 1916) "It certainly seems to follow from your last letter that you are afraid of the father... One must be able to decide whether one loves a woman or not even with stuffed-up nostrils. Of course, I know how difficult it is to differentiate between the psychic and the somatic in one's own person." And in a footnote to Freud's letter to Ferenczi of April 20, 1919, Freud comments tellingly on his assessment of the physical ailments of other members of his group. "Rank is still in bed, but only with a sore throat. Federn has made a fool of himself with pleuritis."

To add to the Oedipal drama, not only does the proposal of marriage to Gizella come through Freud (who writes on March 15, 1917, the day after he receives Ferenczi's request: "your will be done"), but news of the death of Palos (Gizella's husband from whom she was recently divorced) reaches Gizella and Ferenczi the very morning of their wedding day, in March of 1919. She is 54, and he 46 years old.

It is, I think, important to see how very intertwined and how very fraught with triangular (Oedipal) conflicts are what may have been Ferenczi's three most significant relationships: that with Gizella, that with Freud, and that with Gizella's daughter Elma. Furthermore, such intertwining might have 
been the object of analysis had Freud been more sensitive to the need for the analysis of idealization and shame. But Freud's own personal agendas would seem to have gotten in the way, related to the absence of any opportunity he might have had to work through his own shame dynamics with his analyst; Freud had no analyst to set boundaries. To stave off fears of humiliation, rooted in his own childhood experiences (e.g., "that child will come to nothing") and reinforced by his desire to be famous and by his own competitive strivings, Freud needed others to idealize him, and this need blinded him to his analytic responsibilities with respect both to Ferenczi and to himself. Then there was his genuine affection for Ferenczi as a close friend.

In Freud's paper "Psychoanalysis and Telepathy" (1921 S.E. 18 191-192), Freud reports a triangle in which a daughter comes to analysis because the man concerned could not decide between her and her mother. In this case Freud could be referring to Ferenczi's indecision, being split between Gizella and Elma, or to his own (being split between the two women as well). At the very least, Freud had to take a position with respect to Ferenczi's split, one that entailed his own experiences of divided loyalty. ${ }^{2}$

Let me back up now from 1919, the date of Ferenczi's marriage to Gizella, to 1900, the year in which Ferenczi and Gizella began an affair. This is, as you will remember, three years after Ferenczi returns from Vienna having completed his medical training there. There are many important events between 1900 and 1919. But let me focus on a few that seem to me to be particularly crucial for the Freud-Ferenczi relationship.

In February 2, 1908 Ferenczi meets Freud. In August of 1909 Freud, Ferenczi and Jung set out for America where Freud will deliver his Clark Lectures. On the way across the Atlantic, Freud, Jung, and Ferenczi all sit around analyzing each other's dreams. Once at Clark, Freud and Ferenczi would take long walks before Freud's lectures during which Ferenczi would sketch out the lecture Freud would deliver shortly thereafter.

Around 1910, Freud takes Gizella into analysis. In 1910, Freud and Ferenczi spend a vacation in Sicily on the occasion of which Ferenczi requests from Freud openness of a kind that Freud refuses, referencing his disappointments with Fleiss together with homosexual overtones and undertows. In Ferenczi's letter to Freud of October 3, 1910 he speaks of honesty, of an ideal "between two men who tell each other the truth unrelentingly, sacrificing all consideration... That was the ideal I was looking for; I wanted to enjoy the man, not the scholar, in close friendship." Ferenczi then refers to a dream in which he sees Freud naked, and interprets it as an indication of his own wish for "absolute mutual openness." Freud replies on October 6: "Not only have you noticed that I no longer have any need for that full opening of my personality, but you have understood it and correctly 
returned to its traumatic cause...A piece of homosexual investment ${ }^{3}$ has been withdrawn and used for the enlargement of my own ego. I have succeeded where the paranoiac fails." To which Ferenczi replies, referring to the healthy core of his idea of truth and relating it to "the child's urge for truth...I still hold firm to the conviction that it is not honesty but superfluous secrecy that is abnormal..." (Bokanowski, 1998, p. 136).

In July 14, 1911, Ferenczi informs Freud that he has taken Gizella's daughter, Elma, into analysis. That fall, Ferenczi falls in love with Elma and writes to Freud of his difficulties. At Ferenczi's insistence, on New Year's Day 1912, Freud takes Elma into analysis that ends Easter of the same year (1912). Later in 1912 Ferenczi resumes his analysis with Elma. ${ }^{4}$

Then in 1914 Ferenczi enters into analysis with Freud. This bit of analysis lasts only 15 or 20 days because Ferenczi is called to war. The interruption is obviously extremely painful to Ferenczi. In 1914, Freud writes "Observations on Transference-Love" (written in 1914 and published early in 1915). In this paper Freud addresses the subject of boundaries and their pertinence for analytic work, holding out the concept of "transference love" as the portal in the storm of emotions. However, as is clear from the debate between Nussbaum and Friedman (2005) in a recent issue of JAPA, the debate still rages over how like love "transference love" can be, how "real" it is.

Several years earlier in a letter to Jung, Freud himself admitted that the undertows of all-too-real affections are not likely to be done away with easily. Freud writes to Jung on June 7, 1909 about Jung's liaison with Sabina Spielrein: "Such experiences, though painful, are necessary and hard to avoid. Without them, we cannot really know life and what we are dealing with. I myself have never been taken so badly, but I have come very close to it a number of times and had a narrow escape (note the italics). I believe that only grim necessities weighing on my work, and the fact that I was ten years older than yourself when I came to psychoanalysis, have saved me from similar experiences. But no lasting harm is done. They help us to develop the thick skin we need and to dominate 'counter-transference,' which is after all a permanent problem for us; they teach us to displace our own affects to best advantage. They are a blessing in disguise" (quoted in Haynal, 1993, p. 362). This is, significantly, the first recorded reference to the term "countertransference." The term appears for the first time in a published work a year later in "The Future Prospect of Psycho-Analytic Therapy" (1910). Freud was at the time roughly ten years older than Jung, as Gizella was roughly ten years older than Ferenczi. ${ }^{5}$

Ferenczi's second bit of analysis starts at Ferenczi's insistence. In 1916 Freud reluctantly agrees to resume the analysis first from June 14 to July 5, and then from September 26 to October 9 of the same year. The total time of Ferenczi's analysis thus falls short of two months, interrupted by the war. 
Also, the war demonstrated rather different reactions on the part of Freud and Ferenczi. Whereas Ferenczi was actually inducted into the war effort and became increasingly involved in studying war trauma and trauma in general, Freud held his distance and produced an astonishing number of theoretical and technical papers. His theories seemed to have been relatively unaffected by the war. Soon after Ferenczi went to the front, he writes to Freud of the analytic treatment of his army commander, suffering from traumatic reactions to a grenade explosion, referring to it as the "first recorded analysis on horseback" (February 22, 1915 Ferenczi to Freud). While the war did not come between the two, except for cutting short Ferenczi's analysis, it did underscore a difference between Ferenczi's engagement and Freud's aloofness.

In the years immediately following the war, there were a number of psychoanalytic projects (clinic and publishing house) funded first by the Republic of Councils and then privately funded by Anton von Freund, a wealthy Budapest brewer. But when von Freund died, Ferenczi could not access the funds because of the political and economic upheavals of the counter-revolution. ${ }^{6}$

Then in the spring of 1918 Ferenczi is elected President of the International Psychoanalytic Association. ${ }^{7}$ In September of the same year (1918) Ferenczi and Anton von Freund organize the first Psychoanalytic Congress since the Munich congress of 1913 to be held in Budapest. Ferenczi emphasizes the war neuroses and trauma. Obviously World War I overshadows this entire period, as does the Treaty of Trianon, as a result of which Hungary lost most of its territory. ${ }^{8}$

The year 1919 turns out to be fateful for Ferenczi, and filled with events both promising and catastrophic. In March 1919, at Freud's insistence Ferenczi marries Gizella Palos. In April 25, 1919 Ferenczi is appointed to the first position in the world of full professor of psychoanalysis at the University of Budapest in Hungary.

The Bolshevik revolution of 1919 set up the Republic of Councils led by Bela Kun. Although the Commune lasted only 133 days, it produced a number of social reforms and supported psychoanalysis in Budapest (e.g., Ferenczi's chair). "Analysis is being sought after everywhere," Ferenczi to Freud April 12, 1919. However, the Commune was followed by a counterrevolution led by Horthy that introduced a reign of terror governed by a provincial fear of cosmopolitanism; Horthy's capital was the provincial town of Szeged, deliberately slighting the cosmopolitan (and Jewish) Budapest. As a result of the Horthy counter-revolution, Ferenczi is stripped of his professorship in August of 1919.

Some months thereafter, Freud's secret committee prevails upon Ferenczi to resign the presidency of the International and to allow Jones to 
take over, thus moving the headquarters of the International from politically unstable Budapest to London.

In the space of a few short months during the year of 1919, Ferenczi has yielded to Freud's pressure to marry Gizella, stripped of his leadership position (the presidency) of the psychoanalytic movement, and also stripped of his professorship at the university, left with few patients, and confronted with extremely difficult financial circumstances. "Last week," he writes to Freud (June 29, 1919) "I paid 2800 crowns for 18 kilos of pork lard (10 kilos of which were bones and meat, however), which is almost the salary I get for two months as university professor... Only the black coffee is the way it used to be."

Let me now back up to provide the larger context for the relation between Freud and Ferenczi during these years. In 1914, the Austro-Hungarian Empire entered World War I on the side of the Germans. At the end of the war Hungary was penalized by being stripped of $2 / 3$ of its territory and more than $1 / 2$ of its population. The humiliation of the Treaty of Trianon in 1920 endured long after the actual treaty, producing a deep sense of resentment and loss.

\section{FREUD AND FERENCZI; RIVALRY AND SHAME}

The Freud-Ferenczi correspondence sheds new light on the relationship between Freud and Ferenczi; both men were conscious of how they needed to appear in their letters; both men used the letters to express their selfrepresentation and assessments of self-worth (Kilborne, 1999, 2002). The Freud-Ferenczi conflicts were expressed in a number of ways, among them in debates over the relative place of abstinence and gratification, and the ways in which these are believed to be related to regression and to a concept of "working-through." ${ }^{\prime 9}$ Freud $(1912,1914 a, b)$ emphasizes abstinence to allow unconscious wishes to emerge; Ferenczi emphasizes an atmosphere of trust and freedom to heal traumatic disappointments (so they can be worked through in the analytic situation rather than being unconsciously repeated in the outside world).

In his 1929 paper, "The Principle of Relaxation and Neocatharsis," Ferenczi says plainly: "psychoanalysis employs two opposite methods: it produces a heightening of tension by the frustration it imposes and relaxation by the freedom it allows" (p. 115). It is worth noting that the opposite of frustration for Ferenczi is not gratification per se, but rather "freedom." We will see what overtones this emphasis has in the portions of the Freud Ferenczi correspondence to which I will turn shortly.

But first it may be useful to pause in order to consider more fully the implicit role that Ferenczi attributed to shame. He thought that abstinence could humiliate, a notion to which Freud was relatively indifferent. As a 
result of his identification with his own analyst, Freud had trouble differentiating between himself and his analyst, a confusion that could not but lead to boundary difficulties with implications for transference and countertransference. Ferenczi believed that honesty and trust in the analytic relationship (on both sides) promoted freedom and dignity, both of which constituted worthwhile objectives to be promoted in all patients.

At the end of Ferenczi's life, Freud, Jones, and the others, hardening their position of intolerance towards Ferenczi personally (accusing him of being deranged, along with Rank) and professionally, questioned the legitimacy of Ferenczi's place in the psychoanalytic movement. They accused Ferenczi of "mothering" his patients rather than analyzing them. From the vantage point of contemporary psychoanalysis, such an accusation seems unfair to Ferenczi's clinical positions, unnecessarily humiliating to Ferenczi, and onesided, since it privileges the father over the mother and oversimplifies the entire question of gratification versus abstinence.

Behind the supposed technical antinomy (gratification or abstinence) would appear to be the rivalry of Jones towards Ferenczi, and the need for Freud to present himself as the father figure (and not a maternal figure) to all those involved in the psychoanalytic movement. As I hope will become clear, the controversy between abstinence and gratification is in many ways a false dichotomy, used in the service of psychoanalytic politics and personal vendetta, and troubling to anyone grappling with the history of the psychoanalytic movement. Furthermore, the supposed antinomy between gratification and abstinence as used by Jones and the detractors of Ferenczi falsifies essential dynamics of clinical encounters, placing undue emphasis on the supposed power of the father and implicitly deprecating maternal functions. Additionally, no matter who uses the antinomy - whether self-psychologists, intersubjectivists, ego psychologists, or interpersonalists - it contributes to boundary confusions by detracting from respect for the patient and the complexities of the analytic encounter. Obviously abstinence does not necessarily guarantee safe and appropriate boundaries any more than gratification necessarily cures deficits or guarantees empathy.

Bearing in mind the personal underbelly of Ferenczi's theories of trauma and treatment as a way of considering what are always important and difficult technical decisions, and bearing in mind too Ferenczi's tendency to idealize Freud and Freud's tendency to humiliate Ferenczi, listen now to excerpts from the correspondence between 1914 and 1919, the period covering World War I and the election of Ferenczi to the presidency of the IPA.

October 27, 1914 Ferenczi to Freud

"I didn't want to bore you with my boring personal moods.-That is also the reason for the many and long pauses in our correspondence which are for the 
most part my fault." And he concludes by saying he will now "consign this letter, which makes me so ashamed, to the mails."

Freud to Ferenczi November 9, 1914

I conclude from your actions that you still haven't pulled yourself together, and I am very dissatisfied with that.

Ferenczi to Freud December 18, 1914

...Elma is coming to Budapest as a young woman and that may have aroused in me the whole question of my relationship to her, which was not settled in Vienna. But why bring up all these problems, maybe you will take me into treatment again; until then one has to muddle through as best one can.

Freud to Ferenczi (speaking of shame in speaking of melancholia, and with overtones of competitive shaming and devaluation): February 7, 1915. Note Freud's references to idealization and shame, both of which characterized Ferenczi's relation to him.

Melancholia shows a tremendous impoverishment of the ego and a painfully enlarged apprehension of it. Its self-criticism is exaggeratedly conscious and paints for us a picture which we must assume to be correct. The ego is devalued, remains very far behind the ideal, can accomplish nothing, must put up with the severest reproaches, does not deserve to be well looked after, taken care of. So that must really be the state in which it exists. What is noteworthy is the acuity and intactness of the self-observation (of conscience, of ego censorship, of the actual ego). But how did the ego of melancholia get into this state? What did it do to deserve such condemnation? The ego mourns because it has lost its object through devaluation, but it projects this object onto itself and then finds itself devalued. The shadow of the object falls on the ego and obscures it. The process of mourning is carried out not on the object cathexes, but rather on the ego cathexes.

Ferenczi (February 25, 1915) then disagrees with him, in ways that resonate with their relationship difficulties, and that calls to mind Ferenczi's criticism that Freud did not analyze his negative transference. Also, it would appear that Ferenczi is implicitly suggesting that Freud is paranoid because of his disinclination to trust.

I don't believe I misunderstood you. I understood you to mean that in your view the melancholic suicide actually commits a double suicide. He kills himself (his critical ego) and also his beloved (ego), which has proved to be unworthy of him after he (the narcissistic ego) succeeded for a time in deceiving him (the critical ego)! The occasion for the illness was effected by the disappointment in other persons who served as models for the narcissistic ego and the devaluation of whom also reveals one's own worthlessness. Melancholia is thus a case of unfortunate (unworthy) falling in love with one's self, whereas the victim of dementia is happily married to his narcissistic ego, and the paranoid (who is also not 
completely satisfied with himself) understands how to safeguard the appearance of happiness (from himself).

On July 31, 1915 Freud writes to Ferenczi, treating him as the favorite son.

You are now really the only one who still works beside me. The others are all militarily paralyzed.

And Freud confided to Ferenczi his reservations concerning Jones in his letter of December 26, 1915.

Jones' tendency to plagiarize is familiar to me; he once appropriated my essay on suggestion in a similar way. His originality is [as I know from the analysis] inhibited; for that reason he has to satisfy his ambition in this way. Despite all that, he is a good boy-only one has to correct him in this respect.

And in an astonishing letter Ferenczi addresses to Freud about Gizella (February 2, 1916), Ferenczi writes:

I "want to report to you on the details of this evening, when I read your letter aloud to Frau G.... I wanted to know whether I want to marry Frau G. even without [your] advice, completely spontaneously... . I feel like a wayward son who has only mischief to report. But I am also remiss in complete honesty with respect to you-since this is the first condition for improvement. I remind you of my neurotic behavior in the Hotel de France in Palermo. There too, the fear of succumbing to your suggestion in common scientific work and of not writing my own opinion was to blame for my refusal."

And finally, in his letter of May 23, 1919, that fateful year, Ferenczi writes to Freud after having reviewed his correspondence:

On this occasion there arose in me like a gleam the insight that, since the moment in which you advised me against Elma, I have had a resistance toward your own person which could not even be overcome by the attempt at a psychoanalytic cure, and which was responsible for all my sensitivities. With the unc. resentment in my heart, I as a loyal 'son' nevertheless followed all your suggestions, left Elma, again turned to my present wife, with whom I have stayed, despite countless temptations from other quarters... It appears that I can be happy in life and content in work only when I can be and remain in good, indeed the best relations, with you. The realization that in Frau G. I have the best that could befall me-with my constitution-is the first fruit of my inner reconciliation with you. I ask you, don't lose patience with me in the future either. I hope to offer you less occasion for that than in the past.

Ferenczi felt he had been a "blindly dependent son" while Freud was "playing the role of the castrating god" and unable to recognize that he was "the only one who does not have to be analyzed" (1985, pp. 185, 188).

We can see in the correspondence evidence of issues directly pertinent to analytic technique. Ferenczi says he wants to be a "good boy," complains of feeling like a "wayward son," wonders whether there is any being "good" 
in Freud's eyes that does not feel to him (Ferenczi) like obedience and compliance masquerading as confusion. Can Ferenczi conform to what he experiences as Freud's will without feeling such conformity to be compliance with Freud's suggestion? In any number of ways, Ferenczi tries to express the idea that marrying Gizella feels to him like submission, and struggles with wanting it to be an expression of his own opinion and will. Ferenczi cannot come up against Freud directly; he feels that he is wayward, neurotic, confused, incompletely honest, implores Freud to help him since he wants to be able to "improve." Yet to do so Ferenczi must rely on Freud, and in that reliance lies anguish about his own resistances.

Later that same year (October 24, 1916) Freud writes to Ferenczi:

When I said the treatment was at an end, I did not mean it was terminated. The way you rode narcissism instead of discovering the identification with Gezella, which refers in fantasy to marriage with Gizella as completed, would certainly have to enlighten me, but it is at an end because it cannot be continued for at least six months and would thus place itself in the service of avoiding the neurotic intention. [The English translation here is a little obscure.] I haven't received the money. You sent it to a bank which I have nothing to do with. It is incorrect that the bank isn't advising you of it, or that it hasn't sent it to me. There is another parapraxis sitting somewhere in this.

Let us pause to comment on this letter. Apart from seemingly rubbing in the fact that Ferenczi's analysis was not terminated (was Freud's after all?), Freud criticizes and humiliates Ferenczi. What are we to make of the following lines, in the same letter:

it [the analysis] is at an end because it cannot be continued for at least six months and would thus place itself in the service of avoiding the neurotic intention.

What might Freud have meant by suggesting that because his analysis with Ferenczi could not be continued, Ferenczi would use this bit of "reality" in the service of resistance? Who here is responsible for the delay? Might Freud be suggesting that if Ferenczi uses Freud's reluctance to start the analysis again in the service of resistance, this constitutes reason for viewing the analysis as terminated? If so, this is a rather unorthodox view of termination, and suggests that Ferenczi is not worthy of termination.

Then there is the reference to inadequate payment. One wonders what bank Ferenczi sent the payment to and why Freud thought he had nothing to do with it. Was Ferenczi not following Freud's instructions? There are clearly more gracious and considerate ways for an analyst to express his need for money to an analysand, friend, and colleague. 


\section{THE WIDENING GAP}

In the Freud-Ferenczi correspondence, it becomes clear that a rift between the two widens more sharply during the 1920s and then more still in the years before Ferenczi's death. On September 18, 1931 Freud writes to Ferenczi:

There is no doubt that ...you are distancing yourself from me more and more. I say, and hope not: alienating.

A year later the tone grows more condemnatory. Freud to Ferenczi, October 2, 1932

I don't any longer believe that you will rectify yourself...For three years you have been systematically turning away from me, probably developed a personal hostility.

\section{Freud to Ferenczi (October 2, 1932)}

For a couple of years you have systematically turned away from me... Objectively I think I could point out to you the technical errors in your conclusions, but why do so? I am convinced that you would not be accessible to any doubts.

Correspondingly, on Ferenczi's side there is evidence of disappointment and pain over the rift. Ferenczi writes of Freud, "Latest disappointment: He does not love anyone, only himself and his work" (1985, p. 159f).

In their final bit of correspondence, Freud and Ferenczi both demonstrate concern the one for the other. On April 2, 1933 Freud writes:

The differences between us...can wait... it is more important to me that you should recover your health.

Ferenczi dies a few weeks later, having sent Freud a letter expressing his concern for him. Ferenczi to Freud, March 29, 1933:

I advise you to take advantage of what time remains, since the situation is not imminently threatening, to leave for a more stable country, England, for example. Take some patients with you and your daughter Anna.

In Freud's obituary of Ferenczi, Freud writes:

After this summit of achievement, it came about that our friend slowly drifted away from us. On his return from a period of work in America he seemed to withdraw more and more into solitary work, though he had previously taken the liveliest share in all that in all that happened in analytic circles. We learnt that one single problem had monopolized his interest. The need to cure and to help had become paramount in him. He had probably set himself aims which, with our therapeutic means, are altogether out of reach today. From unexhausted springs of emotion the conviction was borne in upon him that one could effect far more with one's patients if one gave them enough of the love which they had longed 
for as children. He wanted to discover how this could be carried out within the framework of the psycho-analytic situation; and so long as he had not succeeded in this, he kept apart, no longer certain, perhaps, of agreement with his friends. (Freud (xxii), 1933, p. 229)

And, finally, in "Analysis Terminable and Interminable," Freud writes ${ }^{10}$ of Ferenczi:

A certain man, who had himself practiced analysis with great success, came to the conclusion that his relations both to men and to women-to men who were his competitors and to the woman he loved-were nevertheless not free from neurotic impediments; and he therefore made himself the subject of an analysis by someone else whom he regarded as superior to himself. This critical illumination of his own self had a completely successful result. He married the woman he loved and turned into a friend and teacher of his supposed rivals. Many years passed in this way, during which his relations with his former analyst also remained unclouded. But then, for no assignable external reason, trouble arose. The man who had been analysed became antagonistic to the analyst and reproached him for having failed to give him a complete analysis. The analyst, he said, ought to have known and to have taken into account the fact that a transference-relation can never be purely positive; he should have given his attention to the possibilities of a negative transference. The analyst defended himself by saying that, at the time of the analysis, there was no sign of a negative transference.... Furthermore, he (the analyst) added not every good relation between an analyst and his subject during and after analysis was to be regarded as a transference; there were also friendly relations which were based in reality and which proved to be viable. (Freud, 1937, pp. 221-222)

This passage, which has been so often quoted, takes on additional meaning in the light of the competitive and shame-ridden conflicts between Freud and Ferenczi. Freud wants to set the record straight: he gave Ferenczi a completed analysis; there were no grounds whatsoever for Ferenczi's accusations that the analysis was not finished. Freud's assertions here are surprising, particularly since the analysis lasted short of eight weeks. How could he not have known that it was unfinished, particularly after Ferenczi's correspondence and all his struggles over marrying Gizella? And who and what did Freud have in mind when he referred to how Ferenczi "turned into a friend and teacher of his supposed rivals?"

As the Freud-Ferenczi correspondence and Ferenczi's Clinical Diaries (1989/1932) make clear, there are many causes of the rift. It is difficult to know to what extent Freud and Ferenczi use theory to rationalize personal slights and narcissistic injuries, and to what extent theoretical differences and the ways in which these are communicated play into the widening gap.

One of the most obvious theoretical manifestations of the rift pertains to Ferenczi's views of trauma and its relation to early mother-infant 
interactions, views that directly affect positions regarding abstinence and gratification. Freud's technical rules, including the rule of abstinence, served many functions, including that of "organizing" both his followers and the idea the public was to have about psychoanalysis. Freud wanted his discipline to survive and to be looked upon as a viable science, and he was concerned with the sexual behaviors of his followers. Ferenczi's "Confusion of Tongues" paper showed up Freud's inconsistencies over abstinence, which might have been one of the reasons why Freud reacted so strongly against it. While telling analysts to follow the rules of analysis, Freud himself was inconsistent in his own adherence to his rule of abstinence, or indeed, to all of his rules. He gave the rat man sardines, told Ferenczi whom to marry, allegedly had an affair with his sister-in-law, and intervened in the case of other followers and anlysands. There was on the one hand the official Freud; and then there was Freud the human being.

As I have noted, Ferenczi's commitment to the treatment of trauma took on renewed significance as a reaction to his wartime experience as well as his determination to establish clinics in Budapest. There is, additionally, another influence, the centrality of which cannot be underestimated: Ferenczi's ties to Rank and, consequently Ferenczi's emphasis on the trauma of birth as the prototype of all subsequent trauma, an emphasis also perceptible in Ferenczi's Thalassa (1924). Such an emphasis marked a clear departure from Freud's theories of sexuality and aggression, and for Ferenczi allowed him to focus on the relation between regression and trauma. For Ferenczi and Rank, Freud's theories of primary aggression and of primary narcissism, together with his emphasis on abstinence, when seen in the light of the trauma of birth and separation anxiety, made little sense clinically. ${ }^{11}$

One-way station along the road to divergence was Ferenczi and Rank's book The Development of Psycho-Analysis, published in 1924. As a result, two groups emerged: the Budapest group (Ferenczi and Rank), on the one side, and the Berlin group (Abraham, Eitingon, and Jones), on the other. Abraham criticized the path of Ferenczi and Rank as seeming "to lead away from psychoanalysis." ${ }^{12}$ The attack on the Budapest group by the Berlin group would have tragic consequences for the history of psychoanalysis, and virtually all the most substantive contributions of the Budapest group would go into eclipse until well after the Second World War.

Thus, Ferenczi fell in Freud's eyes from the status of valued friend and one whom Freud seriously considered as a potential husband for his daughter Mathilde to the status of one for "no assignable reason" became antagonistic and whose psychoanalytic contribution were seriously open to doubt. André Haynal writes, "Is this not the sorrowful history of an unresolved transference, of an unanalysable transference love against the 
background of mingled friendship, love and scientific collaboration" (Haynal, 2005, p. 463)? And Haynal continues: "It was sometimes as if Ferenczi had never written what he wrote: and in some places he simply did not exist. As a result, everything had to be discovered all over again: the significance of trauma and early deficiencies (as in the work of Melanie Klein, Donald Winnicott, Henry Stack Sullivan and others; splitting and borderline structures (as in Otto Kernberg's theory); as well as the fact that every interpretation is more than just an interpretation, as Daniel Stern et al. (1998) recently put it" (Haynal, 2005, p. 463).

It is indeed unfortunate that a clear picture of the two opposing groups within psychoanalysis, the Berlin group and the Budapest group, has not clearly emerged in the mind of the analytic public as a part of our history. And it is equally unfortunate that this opposition has clouded the saga of the Freud-Ferenczi relationship. It was the Berlin group (e.g., Jones and Abraham) who disseminated the myth that both Ferenczi and Rank were mentally ill and unstable. As a result, "regression and, above all, countertransference temporarily disappeared from debate in the 1930's" (Haynal, 1998, p. 37).

\section{A CONFUSION OF TONGUES AND HEARTS}

Ferenczi's concepts of active technique and of mutual analysis may themselves be seen as at least in part a reaction to his shame and humiliation at the hands of Freud: over his needs for gratification and response from Freud, and over his (Ferenczi's) inability to communicate to Freud the pain he felt in such a way that Freud could understand it and communicate that understanding to Ferenczi. Ferenczi longed for an analyst who would not indulge in a "confusion of tongues," the title of what is today perhaps the best known of Ferenczi's papers, and one that picks up on many of the conflicts between Freud and Ferenczi.

Significantly, on July 21,1932 , exactly one month to the day before Ferenczi officially declined the presidency of the International Psychoanalytical Association (August 21, 1932), thereby marking irrevocably his rift with Freud, Ferenczi wrote the entry: "On the Feeling of Shame" in his clinical diary. Three days later (August 27, 1932), Freud wrote to Eitingon that "Ferenczi's refusal was a neurotic action of hostility toward the father and the brothers, in order to preserve the regressive pleasure of playing the mother role with his patients." Note that Freud did not say that Ferenczi favored more gratification in his treatment of patients, and might have reason to do so. Freud referred disapprovingly to Ferenczi's personal need "to preserve the regressive pleasure of playing the mother role," as though Ferenczi were somehow arrested in his development, defective, and not to be taken seriously. 
Later that same summer of 1932 (immediately after his refusal of the presidency, and before going on to Wiesbaden for the 1932 Congress), Ferenczi stopped in Vienna in order to read the "Confusion of Tongues" paper to Freud. Freud had Brill present at the meeting, a gesture that can be construed as one of hostility. Did Freud have Brill there to humiliate Ferenczi when Freud told him explicitly not to publish the paper? Understandably, Ferenczi was deeply hurt by Freud's reaction and by the whole situation, and all the more so when Freud denied having done anything to injure him, viewing Ferenczi's sense of injury as further evidence that Ferenczi was in the wrong.

In his Clinical Diary, Ferenczi notes in striking language his perception of the theoretical rift. Ferenczi refers to

the ease with which Fr[eud] sacrifices the interests of women in favor of male patients. This is consistent with his unilaterally androphile orientation of his theory of sexuality. In this he was followed by nearly all his pupils, myself not excluded. My theory of genitality may have good points, yet in its mode of presentation and its historical reconstruction it clings too closely to the words of the master; a new edition would mean a complete rewriting. (Ferenczi, 1988/1932, p. 187)

In other words, Ferenczi realizes that his theory of trauma and his theories of sexuality were leading him to emphasize the mother-infant relationship in a manner that must inevitably put him at odds with Freud. Might Freud have more vigorously condemned Ferenczi for his emphasis on the seduction hypothesis because Freud had rejected it?

Shortly thereafter (p. 188), Ferenczi writes:

"Fr[eud[ thinks that the clitoris develops and functions earlier than the vagina, that is girls are born with the feeling that they have a penis, and only later do they learn to renounce both this and the mother and to accept vaginal and uterine femininity. Thus he neglects the alternative possibility that instinctual heterosexual orientation (perhaps only in fantasy) is highly developed quite early on, and that masculinity only takes its place for traumatic reasons (primal scene), as a hysterical symptom.

The author may have a personal aversion to spontaneous female-oriented sexuality in women: idealization of the mother. He recoils from the task of having a sexually demanding mother, and having to satisfy her. At some point his mother's passionate nature may have presented him with such a task. (The primal scene may have rendered him relatively impotent.)

Castration of the father, the potent one, as a reaction to the humiliation he experienced, led to the construction of a theory in which the father castrates the son, and, moreover, is then revered by the son as a god. In his conduct Fr[eud[ plays only the role of the castrating god, he wants to ignore the traumatic moment of his own castration in childhood: he is the only one who does not have to be analyzed." 
Here Ferenczi is thinking about the relation between experienced trauma and psychoanalytic theorization. He is wrestling with how to understand Freud's emphasis on castration and potency, and comes to suggest that the ideal of potency that then finds expression in theories of castration is born of humiliation and shame. Ferenczi also suggests that Freud's emphasis on abstinence and his relative avoidance of what he saw as gratification (and came to associate with maternal functions) can also be seen in part as a reaction to experiences of humiliation.

In "The Confusion of Tongues"13 Ferenczi underscores how the analytic situation can cause a re-living of the original trauma. It is possible to read into the paper something of what happened in Ferenczi's analysis with Freud, in which "the language of passion and that of tenderness" had been confounded. It is worthwhile to return to this paper bearing in mind the struggles over issues of shame and humiliation, and the tendency for Freud unwittingly to become a superego figure for Ferenczi (dictating his marriage). If so approached, it is possible to hear in Ferenczi's paper an attempt to formulate feelings of humiliation and shame over not being able to get Freud to recognize how he (Freud) hurt Ferenczi, who felt wounded and abandoned by Freud. Ferenczi struggles for response to traumatic feelings, while Freud emphasizes abstinence, thus seeming to remove himself from Ferenczi's reach.

Martin Bergmann (1998) notes:

"Ferenczi maintained that when the analyst ascribes his own shortcomings to transference reactions on the part of the patient, he damages the patient in three ways: (1) he injures the analysand's capacity to test reality; (2) he behaves like the rationalizing parent in the analysand's infancy; and (3) he demonstrates his lack of courage and reinforces the resistances of the analysand by demonstrating that free associations are not really possible, even within the analytic situation" And Bergmann adds: "Patients then surmise that the psychoanalytic relationship is no more based on truth than are other relationships." (p. 155)

Interestingly, Ernest Jones (Ferenczi's analysand, later analyzed by Abraham in Berlin) joined Freud in believing that the "Confusion of Tongues" paper demonstrated Ferenczi's impairment. More unfortunate still, Freud held that Ferenczi's approach to trauma was a misconstrual of both regression and the transference. Ferenczi might have hit a nerve in Freud. Ferenczi knew that Freud had never experienced shame or transference in relation to his analyst (unless it was mirroring counter-transference and superego shame). Therefore, Ferenczi might have known how to get to Freud's Achilles heel by zooming in on the entire question of negative transference and of the inherently traumatic structure and power differential of the analytic situation. ${ }^{14}$ And Ferenczi might have thought the analytic situation was all 
the more traumatic if Freud did not recognize the need for a mother-transference, and for gratification and regression. Thus, Freud's emphasis on the father to the exclusion of the mother, his emphasis on abstinence rather than gratification, his downplaying of regression, his disinclination to mention the narcissistic quality of his own analysis in speaking about transference, and his phallocentric orientation might have been sore spots to which Freud did not want attention called.

Freud, along with Jones and Abraham, criticized Ferenczi for overemphasizing trauma and for engaging in his "active technique" instead of "analyzing." What are we to make of such pronouncements in view of Freud's pressures on Ferenczi to marry Gizella? And how are we to assess Freud's writings on transference love in the light of Freud's actual relationships? What are we to make of recent discoveries that Freud and his sisterin-law Minna traveled as husband and wife and checked into hotels together (Blumenthal, 2006)? Of his analysis of his daughter, Anna? For Freud, transference love can be circumscribed, at least in theory. But even he admits that the lines between friendship, sexual love, and transference love are far from easy to read, nor are there any universally applicable guidelines.

Such problems go to the core of Freud's wish to be powerful and famous, a wish for which he believed he must present psychoanalysis as a science. They also go to the core of Ferenczi's wish for an intimate friend in Freud, and his lifelong search for a father figure. Which of the two makes the better analyst or therapist? Each makes altogether valid clinical points. However these questions are adjudicated, it is impossible to present a clear picture of the theory of either man without also placing it in the context of present-day debates and, more importantly still, in the context of the human foibles of both men.

Elsewhere (Kilborne, 2002), I have shown how themes of rivalries, conflicts, and shame show up in Freud's own dreams, and how Freud's preoccupation with aggression and guilt would seem at times to function in the service of the avoidance of shame and Oedipal defeat. Criticizing Freud for not allowing him to explore his feelings of "weakness or abnormalities" Ferenczi (1988/32, p. 62) writes:

My own analysis could not be pursued deeply enough because my analyst (by his own admission, of a narcissistic nature) with his strong determination to be healthy and his antipathy towards any weakness or abnormalities, could not follow me into those depths and introduced the "educational" stage too soon.

What Ferenczi sought to express to Freud included his "weaknesses or abnormalities" of which he was already ashamed. An instinct to cover up and to hide, shame experiences trigger defenses against being seen to be regressed, being seen to be traumatized, being seen to feel helpless, etc. ${ }^{15}$ 
Blinded to the dynamics of defeat and humiliation to which Oedipus had drawn him initially, ${ }^{16}$ Freud could not or would not recognize Ferenczi's shame, and therefore failed to respond to Ferenczi's traumatic reactions. By pressing Ferenczi to marry Gizella rather than Elma, Freud infantalized Ferenczi and demanded humiliating submission. Ferenczi attempted to express his trauma, his dependency and idealization of Freud and to give voice to his struggles. Yet when Ferenczi expressed his distress, Freud backed away. Freud's narcissism (and his defense of his position as leader of the psychoanalytic movement) got in the way of his ability to respond as a friend, colleague, and analyst to Ferenczi's injury, with unfortunate consequences for the history of psychoanalysis. Let us hope that today we can learn from the Freud-Ferenczi relationship, and from the theories that grew out of it, and, without ascribing blame to either, try to be ever-mindful of shaming our patients, ever aware of the limitations of theory, and ever attentive to the injuries of our patients.

\section{ACKNOWLEDGMENTS}

This paper, which began at the International Ferenczi Conference in Torino in 2002 organized by Franco Borgogno, has benefited from the comments of both Giselle Galdi and the late Paul Roazen and his colleagues at Harvard, for which I am very grateful.

\section{NOTES}

1. The question of positivism within the history of the social sciences raises a number of important questions about causality. Suffice it to say that I have elsewhere (Kilborne, 1992) linked the rise of positivism in the social sciences to the religious revival of the early 19th century, and to the need for the feeling of being positive, picking up on William James' definition of rationality as "the feeling of what fits."

2.See Andre Haynal (1991, p. 7), who comments on the link between this paper of Freud's and the Ferenczi-Gizella-Elma triangle.

3. A comment that homosexual investment has been withdrawn would seem to constitute an implicit admission that it had been there previously, which might lend more weight to possible difficulties Freud would have had in seeing Elma as a sexual rival, or at the very least, as threatening the intensity of Ferenczi's relation to him.

4.In 1913 Freud writes the "Theme of the Three Caskets," a paper dealing with triangles. How this paper relates to the Freud-Ferenczi relationship is a question beyond the scope of this paper. Suffice it to say here that it relates to relations to the mother, a subject on which Freud and Ferenczi were to diverge more and more markedly. Gizella represents for Ferenczi a mother figure with respect to which the triangulation with Freud makes Freud implicitly the father figure.

5. Freud admitted to Oskar Pfister in a letter of June 5, 1910 that "transference is indeed a cross" (quoted on p. 28). And in a letter to Jung of Dec 6, 1906, Freud writes: "the cure is effected by love" (quoted in Haynal 1998, p. 29).

6. In the wake of the Treaty of Trianon, a number of analysts left Budapest. Alice and Michael Balint left for Berlin and then returned to Budapest in 1924 where they were analyzed by 
Ferenczi and stayed with him. During Ferenczi's years of illness they took care of him and then, after his death in 1933, carried on the psychoanalytic movement in Hungary, leaving only in 1939 because of the Nazi threat. Franz Alexander left for Berlin and then Chicago, followed by Melanie Klein, Ferenczi's analysand, to Berlin where she had a second analysis with Karl Abraham before leaving for London in 1926. While in Budapest Klein worked with Anton von Freund in the "Association for Infant Research" (Moreau-Ricaud, 1998, p. 54). These analysts were followed by Sandor Lorand, Geza Roheim (analyzed by Vilma Kovacs), and Sandor Rado, who established the New York Psychoanalytic Institute in 1931. Roheim, Rado, and Lorand all ended up in New York living on the West side within blocks of each other. See also Vikar (1998).

7. It is a mark of politics that although it was Ferenczi who proposed the idea of an International Psychoanalytical Association (IPA) and was indeed elected president, Ferenczi's photograph was missing among the photographs of past presidents of the International Psychoanalytic Assn. It was not until several years ago that Dr. Horatio Etchegoyen, then president of the International Psychoanalytic Assn., thought to inquire about the lacunae. He contacted Dr. Leo Rangell, who asked me about Ferenczi's presidency. What is to be noted here is how completely the memory of the events of 1919 had been erased in the minds of our analytic community. The events were shameful, Ferenczi was left with the rubble of Hungarian politics. Increasingly, the axis Berlin/Jones and Budapest/Rank split the psychoanalytic world, with Ferenczi becoming a central figure of the Budapest school. This is a complicated story to unfold over the next 15 years.

8. It appears from the correspondence that the funds of the psychoanalytic movement are transferred to Budapest, where Ferenczi and Rank would have the responsibility of disbursing them for various purposes. However, the financial logistics and management of the resources of the psychoanalytic community have never, to my knowledge, been thoroughly described.

9. To what ends did Freud wish to use abstinence? To what ends did Ferenczi want to use gratification? And how much room was there in the ideas each held for discrepancies between what they thought they were doing and what they were actually doing? What effect did their relationship have on the ideas they held, and what effect did their ideas have on their relationship and on their clinical work?

10.It is useful to note that at the beginning of this paper, Freud (1937) explicitly denigrates Rank's theory of trauma (and Ferenczi's with it), noting that Rank "supposed that the true source of neurosis was the act of birth, since this involves the possibility of a child's 'primal fixation' to his mother not being surmounted but persisting as a 'primal repression'. Rank hope that if this primal trauma were dealt with by a subsequent analysis the whole neurosis would be got rid of. Thus this one small piece of analytic work would save the necessity for all the rest" (p. 216).

11. Of Freud's renewed interest in separation anxiety, Andre Haynal writes that in Inhibition, Symptoms and Anxiety (1926) such renewed interest "can best be understood in the context of his dialogue with Rank...The dialogue with Freud gave Ferenczi and Rank the impetus to explore the themes of regression and early relationships with the mother centered on the interaction that takes place in the psychoanalytic situation, and resulted in their wondering how a psychoanalytic theory could be developed on the basis of this communication" (Haynal, 1998, p. 36). Haynal adds that after Ferenczi's death and without any reference to Ferenczi, Freud returned to the subject of early trauma, narcissistic mortification, and splitting in Moses and Monotheism (Haynal, 2005, p. 464).

12.Quoted in Haynal (1998, p. 33).

13. The original title was "The Passions and their influence on the sexual and character development of children." 
14.Bergmann (1998) observes that Ferenczi did not subscribe to Freud's distinction between narcissistic and traumatic neuroses, and in fact "did not believe in any criteria of analyzability" (p. 154).

15.Ferenczi felt he had been a "blindly dependent son" while Freud was "playing the role of the castrating god" and unable to recognize that he was "the only one who does not have to be analyzed" (Ferenczi, 1988/1932, 185, 188).

16.Also important is what Ferenczi refers to in the "Confusion of Tongues" paper as "tenderness." Because in part of his own personal struggles, Ferenczi focused on understanding the nature of the childhood trauma and humiliation, realized how essential regression is in working such trauma through, and, consequently, how important it is for the analyst to recognize whatever in the analytic situation contributes to its repetition rather than its working-through. Ferenczi, particularly, struggled to describe regression (whatever "regression" is construed to mean) experientially, along with the shameful, regressive fears of separation from the analyst, exacerbated by his relationship with Freud.

\section{REFERENCES}

Bergmann, M.S. (1998). The tragic encounter between Freud and Ferenczi. In P. Rudnytsky, A. Bokay \& P. Giampieri-Deutsch (Eds.), Ferenczi's turn in psychoanalysis (pp. 145-159). New York: New York University Press.

Bokanowski, T.M. (1998). Sandor Ferenczi: Negative transference and transference depression. In P. Rudnytsky, A. Bokay \& P. Giampieri-Deutsch (Eds.), Ferenczi's turn in psychoanalysis (pp. 120-144). New York: New York University Press.

Blumenthal, R. (2006, December 24). Hotel lag hints at illicit desire that Dr. Freud did not Repress. The New York Times, pp. 1A, 4A.

Ferenczi, S. (1924 [1968]). Thalassa: A theory of genitality, H.A. Bunker (Trans.). New York: Norton.

Ferenczi, S. (1930). The Principle of relaxation and neocatharsis. International Journal of Psychoanalysis, 11, 428-443.

Ferenczi, S. (1988/1932). Clinical diary of Sandor Ferenczi, J. Dupont (Ed.), M. Balint \& N. Zarday Jackson (Trans.). Cambridge: Harvard University Press.

Freud, S. (1912). Types of onset of neurosis. Vol. 12, pp. 227-238.

Freud, S. (1913). The theme of the three caskets. Vol. 12, pp. 89-302.

Freud, S. (1914a). Observations on transference love. Vol. 12, pp. 57-171.

Freud, S. (1914b). On Narcissism. Vol. 14, pp. 68-102.

Freud, S. (1933). Sandor Ferenczi. Vol. 22, pp. 227-232.

Freud, S. (1937). Analysis terminable and interminable. Vol. 23, pp. 216-253.

Freud, S. (1939). Moses and monotheism. Vol. 23, pp. 7-140.

Haynal, A. (1991) (with Ernst Falzeder) Healing through love? A unique dialogue in the history of psychoanalysis. Free Associations, 2, 1-20.

Haynal, A. (1993) (with Ernst Falzeder) Slaying the dragons of the past or cooking the hare in the present: A historical view on affects and in the psychoanalytic encounter. Psychoanalytic Inquiry, 13(4), 357-371.

Haynal, A. (1998). Freud and his intellectual environment: The case of Sandor Ferenczi. In P. Rudnytsky, A. Bokay \& P. Giampieri-Deutsch (Eds.), Ferenczi's turn in psychoanalysis (pp. 25-40). New York: New York University Press.

Haynal, A. (2005). In the shadow of a controversy: Freud and Ferenczi 1925-33. International Journal of Psychoanalysis, 86, 457-466. 
Kilborne, B. (1992). Positivism and its vicissitudes: The role of faith in the social sciences. Journal of the History of the Behavioral Sciences, 28(3), 352-370.

Kilborne, B. (1999). When trauma strikes the soul; trauma, regression and psychic pain. American Journal of Psychoanalysis, 59(4), 385-402.

Kilborne, B. (2002). Disappearing persons: Shame and appearance. Albany: SUNY Press.

Moreau-Ricaud, M. (1998). The founding of the Budapest School Ferenczi's Turn in Psychoanalysis. In P. Rudnytsky, A. Bokay \& P. Giampieri-Deutsch (Eds.), Ferenczi's turn in psychoanalysis (pp. 41-59). New York: New York University Press.

Nussbaum, M. (2005). Comment on Freidman (Is there a special psychoanalytic love?). Journal of the American Psychoanalytic Association, 53(2), 377-384.

\section{Further Recommended Reading}

Dupont, J. (1994). Freud's analysis of Ferenczi as revealed by their correspondence. International Journal of Psychoanalysis, 75, 301-320.Ferenczi, S. (1996a). The correspondence of Sigmund Freud and Sandor Ferenczi 1914-1919 Vol. 2, E. Falzeder \& E. Brabant (Eds.), Cambridge, MA: Harvard University Press.

Ferenczi, S. (1996a). The correspondence of Sigmund Freud and Sandor Ferenczi 1914-1919 Vol. 2, E. Falzeder \& E. Brabant (Eds.), Cambridge, MA: Harvard University Press.

Ferenczi, S. (1996b). The correspondence of Sigmund Freud and Sandor Ferenczi vol 3. 1920-1933 E. Brabant \& E. Falzeder (Eds.), Cambridge, MA: Harvard University Press.

Freud, S. (1900-1901). Interpretation of dreams. Vols. 4-5.

Freud, S. (1905). Three essays on a theory of sexuality. Vol. 7, pp. 30-243.

Freud, S. (1974). Standard edition 25 vols. London: Hogarth Press.

Gedo, J. (1998). O, Patria Mia. In P. Rudnytsky, A. Bokay \& P. Giampieri-Deutsch (Eds.), Ferenczi's turn in psychoanalysis (pp. 77-88). New York: New York University Press.

Rudnytsky, P. (Ed.) (1998). Introduction. In Ferenczi's turn in psychoanalysis (pp 1-24). New York: New York University Press.

Rudnytsky, P., Bokay, A. \& Giampieri-Deutsch, P. (Eds.) (1998). Ferenczi's turn in psychoanalysis. New York: New York University Press.

Vikar, G. (1998). The Budapest school of psychoanalysis. In P. Rudnytsky, A. Bokay \& P. Giampieri-Deutsch (Eds.), Ferenczi's turn in psychoanalysis (pp. 60-76). New York: New York University Press. 